\title{
Survey of Precise Leveling ArRay Grand Teton National PARK
}

\author{
ARTHUR G. SYLVESTER $\downarrow$ GEOLOGICAL SCIENCES \\ UNIVERSITY OF CALIFORNIA $\downarrow$ SANTA BARBARA \\ ROBERT B. SMITH $\downarrow$ GEOLOGY \& GEOPHYSICS \\ UNIVERSITY OF UTAH $\downarrow$ SALT LAKE CITY
}

\section{$\downarrow \quad$ SUMMARY}

Fifteen permanent bench marks were established east and south of the existing $22 \mathrm{~km}$-long line of 50 bench marks across the Teton normal fault in Grand Teton National Park to compare height changes of Jackson Hole relative to the Teton Range on the west and Shadow Mountain on the east.

The new bench marks, together with three other agency bench marks and three temporary bench marks, constitute a $7.8 \mathrm{~km}$-long extension to the existing line tied to the old line at bench mark GT01.

The new bench marks were precisely leveled between 30 August and 5 September 1994. Misclosure of the double-run survey was $0.86 \mathrm{~mm}$, thus the precision of the total survey is 1 part in 10 million. If the misclosure is simply spread equally among the (n-1) bench marks, then the probable error associated with the relative height of a single bench mark is effectively zero.

\section{$\downarrow \quad$ INTRODUCTION}

A leveling array was established across the Teton normal fault in summer, 1988, by John Byrd and Chuck Meertens (Byrd, et al., 1989) to search for minute vertical displacements on the Teton Fault due to interseismic activity on the fault. With some additions, that array comprises 50 permanent bench marks in an irregular line having a total length of $22,145 \mathrm{~m}$.

The line was surveyed in 1988, 1989, 1991, and 1993 in each case to a standard deviation of a few parts in 10 million (Sylvester et al., 1991; Byrd 1991). Compared to the initial survey in 1988, the 1993 survey revealed that the floor of Jackson Hole between the Snake River and the Teton Range tilted eastward about 12 microradians toward the Snake River, opposite to the sense of tilt in recent geologic time, judging from the southwestward slope of the valley toward the Teton Range front.

Eastward tilt may be related to lowering of the water table due to the decreased precipitation between 1991 and 1993. This interpretation may be tested by extending the line eastward across the river into bedrock east of Jackson Hole and then resurveying both the extension and the old line in the future and comparing the observations with the 1993 survey of the old line together with the 1994 survey of the extension. The extension, described and referred to herein as the Lost Creek extension, carries the line eastward across the Snake River to Shadow Mountain, so that the leveling line across Jackson Hole is tied to bedrock in the mountain ranges that bound it on the east and west.

The Lost Creek extension commences at the eastern termination of the old line at the east edge of 


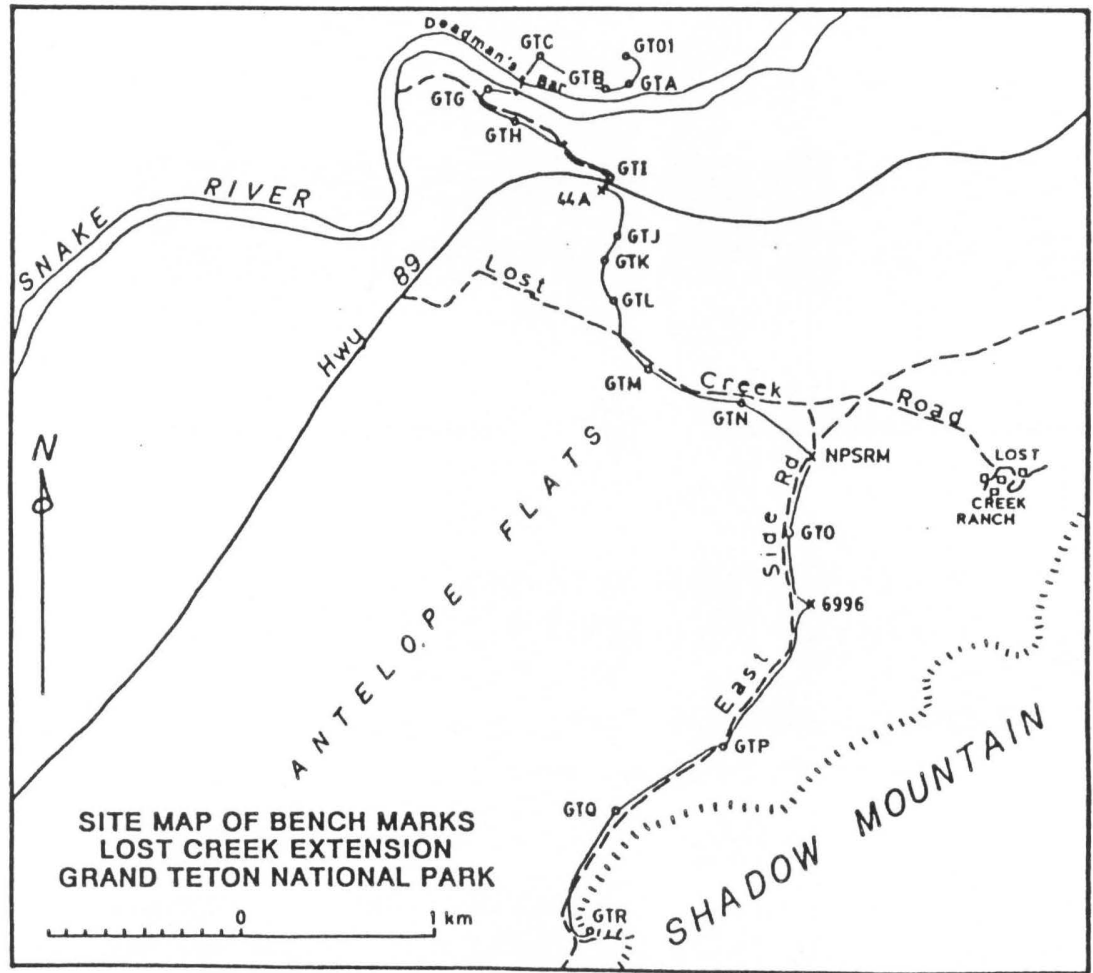

Figure 1. Site map of bench marks Lost Creek extension Grand Teton National Park

Baseline Flat at bench mark GT01 (Fig. 1). It proceeds south and west down the river bank of the Snake River to the north bank of the river. The line extends across the river to the south river bank by using a gravel bar in the center of the river as a stepping stone; thence it extends $150 \mathrm{~m}$ westward along the south shore to a point where the first terrace may be ascended; thence it follows a paved and gravel road eastward to Highway 89. It crosses the highway and proceeds south-southeastward along a horsetrail in a small canyon to an improved gravel road on Antelope Flats that leads eastward to Lost Creek Ranch. At a point about one-half kilometer west of the ranch, the line turns abruptly southward and extends $3 \mathrm{~km}$ along a gravel road, herein called East Side road, to a point where that road intersects bedrock (Love et al., 1992) on the front of Shadow Mountain.

\section{BENCH MARKS}

Bench marks are of three types: Class B rod marks (Floyd, 1978) which are coupled $2 \mathrm{~cm}$ - diameter steel rods, driven to refusal, $4 \mathrm{~cm}$ diameter, stainless steel plugs cemented into holes drilled in bedrock or large boulders which are embedded in glacio-fluvial allluvium or moraine, and $10 \mathrm{~cm}$-diameter pipes of unknown length capped with a standard $10 \mathrm{~cm}$-diameter bronze disk set by other agencies. Minimum length of the Class B rod marks is $1 \mathrm{~m}$, and the maximum length is $3 \mathrm{~m}$. Each Class B rod mark is tipped by a r cm-diameter stainless steel rod, $10 \mathrm{~cm}$ long, which is screwed firmly to the top of the steel rod and cemented with Locitite $^{T M}$. The top of each rod is nearly flush with the ground surface and is encased in a $0.5 \mathrm{~m}$-long, $20 \mathrm{~cm}$-diameter PVC ${ }^{\mathrm{TM}}$ pipe; the space between the rod and the pipe is backfilled with sand to the base of the stainless steel tip. The top of each kind of bench mark is rounded, so that the base of the leveling rod makes a point contact with it.

Bench marks are generally about $500 \mathrm{~m}$ from one another, but some are as close as $122 \mathrm{~m}$ and as far as $920 \mathrm{~m}$. 


\section{EQUIPMENT AND METHODS}

The Lost Creek extension was broken into six segments and surveyed by a single crew. The misclosure of each segment was combined with those of the other segments to yield height differences among all of the bench marks as well as a total closure error. Personnel were apportioned so that there were two rodmen, an instrument man, and a recorder who doubled as an umbrella man.

The north and west parts of the extension were leveled with a shaded Wild N3 tilting level together with a matched pair of strut-supported, doubled-scale, Wild GPL-3 invar leveling rods, serial numbers $6477 \mathrm{~A}$ and $\mathrm{B}$. These rods were last calibrated in October 1993. The remainder of the extension was surveyed with a Leitz NA3000 automatic level and strut-supported, bar-coded, invar rods. The instruments received routine, factory-authorized maintenance and adjustment one week before this project.

All leveling was double run with balanced sights. Length of shots from the N3 to rod was no more than $23 \mathrm{~m}$, whereas from NA3000 to the barcoded rods the shot lengths were typically in the 24$26 \mathrm{~m}$ range. With the $\mathrm{N} 3$, left rod readings were permitted to deviate from the right rod reading by no more than $0.010 \mathrm{~cm}$, else the observation was repeated. A temperature reading was taken at the instrument at a height from 1 to $1.5 \mathrm{~m}$ above the ground surface for nearly every shot. The A-rod of each pair was always placed on a permanent bench mark to minimize the error due to the differences in rod lengths. In order to minimize personnel errors, each instrument man shot the backrun of his/her forerun.

The shot across the Snake River was accomplished with a shaded Leitz NA3000 automatic level and its set of bar-coded, $3 \mathrm{~m}$-long invar rods. The instrument was set up on a gravel bar in the middle of the river at a point that was $39.92 \mathrm{~m}$ from the rod on the north river bank and $39.68 \mathrm{~m}$ from that on the south bank. The height difference between the two bench marks was observed 25 times in one half hour. Throughout that time, the face of the rod on the south shore was shaded, whereas that on the north side was usually in full sun except when an occasional cloud passed overhead. A gusty breeze blew variably through the half hour survey. The height difference was determined by taking the mean and standard of the 25 shots.

Surveying typically commenced about $8: 30$ AM and terminated about 5:30 PM. Temperatures typically ranged from $13^{\circ} \mathrm{C}$ in the early morning to $26^{\circ} \mathrm{C}$ in the mid-afternoon. The sky was generally cloudless. The air was usually calm each morning, but strong gusty winds prevailed on September 3 and 4.

Personnel for the 1994 survey were: Arthur G. Sylvester, David Morey (University of Utah), Eric Johnson, Jane Heinemann, and Greg Bishop.

\section{$\downarrow \quad$ RESULTS}

Observed heights and cumulative stadia distances of bench marks relative to GT01 are presented in Table 1. GT01, which is the easternmost bench mark of the old line, is arbitrarily assigned a height and distance of zero.

\begin{tabular}{|c|c|c|}
\hline \multicolumn{3}{|c|}{ Table 1. Observed heights of bench marks, Lost Creek extension Teton } \\
fault crossing line, Grand Teton National Park. 1994. \\
\hline \multicolumn{2}{|c|}{ GT01 is arbitrarily assigned a height and distance of 0.0 } \\
\hline BENCHMARK & 1994 HEIGHT & CUULATIVE STADIA \\
& (METERS) & DISTANCE (METERS) \\
\hline GT01 & $0.00000 \pm 0.00009$ & $0.0 \pm 0.5 \mathrm{~m}$ \\
GTA & -20.77070 & 304.7 \\
GTB & -30.03180 & 436.8 \\
GTC & -33.39310 & 787.2 \\
TPGT1 & -39.05380 & 1033.7 \\
TPGT2 & -40.07488 & 1113.3 \\
GTG & -33.59716 & 1365.2 \\
GTH & -20.03590 & 1709.7 \\
TPGT3 & -8.66560 & 1964.4 \\
GT1 & 18.53240 & 2367.2 \\
44A & 17.28041 & 2417.2 \\
GTJ & 21.03123 & 2801.7 \\
GTK & 32.33760 & 2924.3 \\
GTL & 54.96620 & 3177.7 \\
GTM & 59.06341 & 3532.8 \\
GTN & 68.86570 & 4267.0 \\
NPSR & 68.55210 & 4597.2 \\
GTO & 68.14514 & 5048.0 \\
6996 & 74.17454 & 5537.2 \\
GTP & 66.52821 & 6467.9 \\
GTQ & 59.35568 & 7140.2 \\
GTR & 47.30230 & 7832.8 \\
\hline
\end{tabular}

Closure errors, leveling precision, length, and date for the surveys of the segments are presented in Table 2. Segment lengths were chosen on the basis of what could be a double-run in a day or one-half of a day between one or more two permanent bench marks.

Closure data in Table 2 represent the misclosure between the forward and backward runs 
of a segment. Our allowable closure error for "tectonic precision" is $1 \mathrm{~mm} \mathrm{x} \mathrm{L^{-1/2 }}$ where $\mathrm{L}$ is the one-way length of the line in kilometers, whereas "first order precision" is $2 \mathrm{~mm} \times \mathrm{L}^{-1 / 2}$ (Federal Geodetic Commission, 1984).

We achieved "tectonic precision" in four of the six segments, and "first order precision" in the other two segments. The ratio of the sum of the misclosures $+0.86 \mathrm{~mm}$, to the total length of the line, $7832.8 \mathrm{~m}$, yields a standard deviation of $1 \mathrm{x}$ $10^{-7} \mathrm{ppm}$ (Table 2), which qualifies the precision of the entire survey as "tectonic first order."

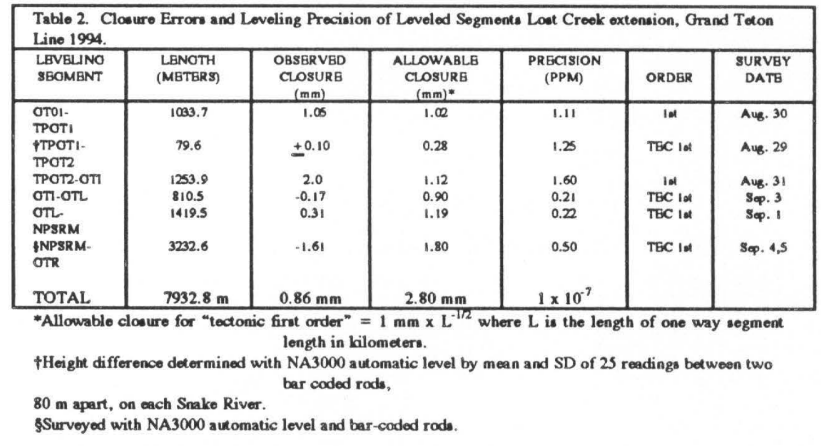

\section{$\downarrow \quad$ CONCLUSIONS}

Successful establishment and survey of bench marks in this $7.8 \mathrm{~km}$-long extension to a standard deviation of $0.1 \mathrm{ppm}$ means that we now have a line of 70 permanent, precisely surveyed bench marks that extends $30 \mathrm{~km}$ westward across Grand Teton National Park from Shadow Mountain, across Jackson Hole (Antelope and Baseline Flats) and the Teton fault, into the core of the Teton Range.

Comparison of future surveys of comparable precision with bench mark heights obtained from the old part of the line in 1993 and the new extension in 1994 will allow us to determine not only the amount and sense of seismic and interseismic displacement across the Teton fault to within a couple millimeters, but also the amount and sense of tilt of Jackson Hole relative to the bounding mountain ranges to within one or two microradians. This information ought to tell us more about the mechanics of the Teton fault and its shape at depth in future during large magnitude earthquakes, as well as the relative roles of nontectonic vs. tectonic mechanisms that cause the floor of Jackson Hole to tilt in the time intervals between those large earthquakes.

\section{LITERATURE CITED}

Byrd, J.O.D., R.B. Smith and A.G. Sylvester. 1989. Bench mark descriptions, 1st-order level line, Cascade Canyon to Deadman's Bar, Grand Teton National Park, Wyoming. Department of Geology \& Geophysics internal report, University of Utah, Salt Lake City. 23 pp.

Byrd, J.O.D. 1991. Paleoseismicity of the southern section of the Teton normal fault, Wyoming. Geological Society of America Abstracts with Programs 23(5), 481.

Federal Geodetic Commission. 1984. Standards and specifications for geodetic control networks. National Geodetic Survey, Rockville, Maryland. $31 \mathrm{pp}$.

Floyd, R.P. 1978. Geodetic bench marks. NOAA Manual NOS NGT 1, National Oceanic and Atmospheric Administration, Washington, D.C. $31 \mathrm{pp}$.

Love, J.D., J.C. Reed, Jr., and A.C. Christiansen. 1992. Geologic map of Grand Teton National Park, Teton County, Wyoming. U.S. Geological Survey Miscellaneous Investigations Series Map I-2031, scale 1:62,500.

Sylvester, A.G., J.O.D. Byrd, and R.B. Smith. 1991. Geodetic evidence for aseismic reverse creep across the Teton fault, Teton Range, Wyoming. Geophysical Research Letters 18(6), 1083-1086. 


\section{APPENDIX 1}

\section{DESCRIPTIONS OF NEW AND AUZILIARY BENCH MARKS}

GTA - $10 \mathrm{~cm}$-long, stainless steel rod with beveled top that projects $2 \mathrm{~cm}$ above the surface of a prominent, massive, sugary, granitic boulder, $1 \mathrm{~m} \mathrm{x} 1 \mathrm{~m}$ at the base and $1 / 2 \mathrm{~m}$ high. The boulder overlooks the Snake River at the southwest corner of an old, obliterated ranch site $100 \mathrm{~m}$ southwest of the end of a dirt rod that proceeds

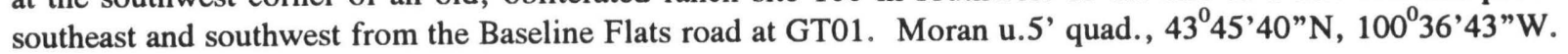

GTB - Class B rod point, $2.5 \mathrm{~m}$ long, driven to refusal in, and nearly flush with the surface at the east end of the first main terrace above the north side of the Snake River. Upper $1 / 2 \mathrm{~m}$ sheathed in $20 \mathrm{~cm}$-diam. PVC pipe. Moran 7.5” quad., $43^{0} 45^{\prime} 34^{\prime \prime} \mathrm{N}, 110^{0} 36^{\prime} 33^{\prime \prime W}$.

GTC - Class B rod point, $3 \mathrm{~m}$ long, driven to refusal in, and nearly flush with the surface at the west end of the first main terrace above the north side of the Snake river. Upper $1 / 2 \mathrm{~m}$ sheathed in $20 \mathrm{~cm}$-diam. PVC pipe. $43^{\circ} 45^{\prime} 42$ "N, $110^{0} 37^{\prime} 04^{\prime \prime} \mathrm{W}$.

GTD - Class B rod point, $1.5 \mathrm{~m}$ long, driven to refusal in, and nearly flush with the surface on the low flat above the north side of the Snake River. Upper $1 / 2 \mathrm{~m}$ sheathed in $20 \mathrm{~cm}$-diam. PVC pipe. Not used in 1994 survey.

GTE - Class B rod point, $1.5 \mathrm{~m}$ long, driven to refusal in, and nearly flush with the surface of the beach on the north side of the Snake River. A lone cottonwood tree on the south face of the main river bank bears $N 15^{\circ} \mathrm{E}$ from the bench mark. Not used in 1994 survey.

GTF - $10 \mathrm{~cm}$-long, stainless steel rod with beveled top that projects $2 \mathrm{~cm}$ above the surface of the east flank of an isolated, polished granitic boulder, $3 \mathrm{~m} \mathrm{x} 2 \mathrm{~m}$ at the base and $1 \mathrm{~m}$ high. The boulder is located in the middle of the active channel of the Snake River. Not used in the 1994 survey.

GTG - Class B rod point, $3.5 \mathrm{~m}$ long, driven to refusal in, and nearly flush with the surface of river terrace at a point $41 \mathrm{~m}$ north of the center line of the gravel road leading across an alluvial flat to the Deadman's Bar boat put-in. Bench mark is at the northeast corner of the flat, $4 \mathrm{~m}$ south of the edge of the flat and from an unimproved, informal trail that leads downward to the next terrace level and the Snake River. Upper $1 / 2 \mathrm{~m}$ sheathed in $20 \mathrm{~cm}$-diam. PVC pipe. Bearing to Grand Teton $=261^{\circ}$. Elevation 6640'a.s.1. Moran 7.5' quad., $43^{\circ} 45^{\prime} 34^{\prime \prime N}, 110^{0} 37^{\prime} 17^{\prime \prime} \mathrm{W}$.

GTH - $10 \mathrm{~cm}$-long, stainless steel rod with beveled top that projects $2 \mathrm{~cm}$ above the surface of a pyramidal shaped, lichen-covered boulder, $1 \mathrm{~m} \mathrm{x} 1 \mathrm{~m}$ at the base and $1 / 2 \mathrm{~m}$ high. The boulder is located on the second main bench above the Snake River, about $20 \mathrm{~m}$ south of the gravel road that leads to the Deadman's Bar boat put-in, and about $400 \mathrm{~m}$ east of the put-in. Elevation $6670^{\prime}$ a.s.l. Moran $7.5^{\prime}$ quad., $43^{\circ} 45^{\prime} 30^{\prime \prime} \mathrm{N}, 11^{\circ} 37^{\prime} 08^{\prime \prime} \mathrm{W}$.

GTI $-10 \mathrm{~cm}$-long, stainless steel rod with beveled top that projects $2 \mathrm{~cm}$ above the surface of a quartzite boulder, having a surface $1 \mathrm{~m} \mathrm{x} 1.5 \mathrm{~m}$ and projects $10 \mathrm{~cm}$ above the ground surface. The boulder is located at the northeast corner of the T-intersection of the Deadman's Bar road and State Highway 89, about $25 \mathrm{~m}$ from the center line of each road. Elevation $6830^{\prime}$ 'a.s.l. Moran $7.5^{\prime}$ quad., $43^{\circ} 45^{\prime} 19^{\prime \prime} \mathrm{N}, 110^{\circ} 36^{\prime} 46^{\prime \prime} \mathrm{W}$.

44A - $10 \mathrm{~cm}$-diameter, stainless steel disk in concrete, set nearly flush with the ground surface, and set and stamped 44A by U.S. Bureau of Public Roads, $25 \mathrm{~m}$ south of the center line of State highway 89 at the intersection of that highway with the Deadman's Bar road, and 50 south and across the highway from GTI. Elevation 6825'a.s.1. Moran 7.5' quad., 430 $36^{\prime} 45^{\prime}$ 'W. 
GTJ - $10 \mathrm{~cm}$-long, stainless steel rod with beveled top that projects $2 \mathrm{~cm}$ above the surface of a volcanic boulder, having a surface $0.5 \mathrm{~m} \mathrm{x} 0.5 \mathrm{~m}$ and projects $30 \mathrm{~cm}$ above the ground surface. The boulder is located in canyon bottom about $4 \mathrm{~m}$ east of a horse trail leading from the intersection of State Highway 89 and Deadman' Bar road to Lost Creek Ranch. It is about $360 \mathrm{~m}$ south of that intersection at the place where the canyon begins to bend from south to east. Elevation 6840'a.s.1. Moran 7.5' quad., $43^{\circ} 45^{\prime} 03^{\prime \prime} \mathrm{N}, 110^{\circ} 36^{\prime} 43^{\prime \prime} \mathrm{W}$.

GTK - Class B rod point, $1.5 \mathrm{~m}$ long, driven to refusal in, and nearly flush with the surface at a point about $10 \mathrm{~m}$ west of the horse trail leading from the intersection of State Highway 89 and Deadman's Bar road to Lost Creek Ranch. It is located on a little flat between the two steep parts of the horse trail approximately $100 \mathrm{~m}$ south of GTJ. Upper $1 / 2 \mathrm{~m}$ sheathed in $20 \mathrm{~cm}$-diam. PVC pipe. Grand Teton not visible from this bench mark. Elevation 6860'a.s.1. Moran 7.5' quad., $43^{\circ} 45^{\prime} 00^{\prime \prime} \mathrm{N}, 110^{\circ} 36^{\prime} 48^{\prime \prime} \mathrm{W}$.

GTL - Class B rod point, $1.5 \mathrm{~m}$ long, driven to refusal in, and nearly flush with the surface at a point about $10 \mathrm{~m}$ south of horse trail where it comes out of the canyon that carried the trail south from the T-intersection of State Highway 89 and the Deadman's Bar road. The horse trail bends eastward to follow the crest of an east-west ridge to Lost Creek Ranch, whereas the leveling line proceeds across the north edge of Antelope Flats to Lost Creek road. Upper $1 / 2 \mathrm{~m}$ sheathed in $20 \mathrm{~cm}$-diam. PVC pipe. Bearing to Grand Teton $=267^{\circ}$. Elevation 6910'a.s.l. Shadow Mountain 7.5' quad., $43^{\circ} 44^{\prime} 57^{\prime} \mathrm{N}, 110^{\circ} 36^{\prime} 47^{\prime} \mathrm{W}$.

GTM - $10 \mathrm{~cm}$-long, stainless steel rod with beveled top that projects $2 \mathrm{~cm}$ above the surface of a quartzite boulder, having a surface $0.5 \mathrm{~m} \times 0.5 \mathrm{~m}$ and projects $5 \mathrm{~cm}$ above the ground surface. The boulder is located in 5 $\mathrm{m}$ south of the center line of gravel road to Lost Creek Ranch and about $9 \mathrm{~m}$ east of $1 \mathrm{~m} \mathrm{x} 1 \mathrm{~m} \mathrm{x} 1 \mathrm{~m}$ volcanic boulder located at elevation point $6950^{\prime}$ on $15^{\prime}$ topographic quadrangle map. Bearing to Grand Teton $=268^{\circ}$. Shadow Mountain $7.5^{\prime}$ quad., $43^{\circ} 44^{\prime} 47^{\prime \prime} \mathrm{N}, 10^{\circ} 36^{\prime} 37^{\prime \prime} \mathrm{W}$.

GTN - $10 \mathrm{~cm}$-long, stainless steel rod with beveled top that projects $2 \mathrm{~cm}$ above the surface of a pyramidal shaped, lichen-covered quartzite boulder, $1 \mathrm{~m} \mathrm{x} 1 / 2 \mathrm{~m}$ at the base and $20 \mathrm{~cm}$ high. The boulder is located $8 \mathrm{~m}$ south of the center line of Lost Creek Road, about $150 \mathrm{~m}$ west of the wye intersection of that road and the East Side Road. Bearing to Grand Teton $=268^{\circ}$. Elevation 6970'a.s.1. Shadow Mountain 7.5' quad., 43 $44^{\prime} 40^{\prime \prime} \mathrm{N}$, $110^{\circ} 36^{\prime} 08^{\prime \prime} \mathrm{W}$.

GTO - $10 \mathrm{~cm}$-long, stainless steel rod with beveled top that prjects $2 \mathrm{~cm}$ above the surface of a volcanic boulder, $1 \mathrm{~m} \mathrm{x} 1 / 2 \mathrm{~m}$ at the base and $1 / 4 \mathrm{~m}$ high. The boulder is located $17 \mathrm{~m}$ east of the center line of the East Side Road, and about half way between NPS reference mark and NPS boundary corner, and $35 \mathrm{~m}, 144^{\circ}$ from power pole KA 135A. Bearing to Grand Teton $=270^{\circ}$. Elevation $=6970$ 'a.s.1. Shadow Mountain 7.5' quad., $43^{\circ} 44^{\prime} 18^{\prime \prime} \mathrm{N}, 110^{0} 36^{\prime} 05^{\prime \prime} \mathrm{W}$.

GTP - Class B rod point, $3 \mathrm{~m}$ long, driven to refusal in, and nearly flush with the surface at the northeast corner of the intersection of the East Side Road and a dirt track that bears $135^{\circ}$ from the same road to the section corner at elevation 6986'. The bench mark is $10 \mathrm{~m}$ from the center line of each road and about $100 \mathrm{~m}$ northeast of the base of a nearby isolated hill. Upper $1 / 2 \mathrm{~m}$ sheathed in $20 \mathrm{~cm}$-diam. PVC pipe. Bearing to Grand Teton $=274^{\circ}$.

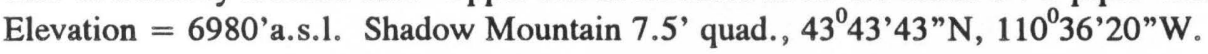

GTQ - Class B rod point, $1.5 \mathrm{~m}$ long, driven to refusal in, and nearly flush with the surface between the intersection of the East Side Road and the powerline road, about $10 \mathrm{~m}$ west of the center line of the East Side Road, and $45 \mathrm{~m}, 168^{\circ}$ from power pole KM121 and $63 \mathrm{~m}, 216^{\circ}$ from power pole 120 , and about $20 \mathrm{~m}$ south of a lone, small pine tree. Upper $1 / 2 \mathrm{~m}$ sheathed in $20 \mathrm{~cm}$-diam. PVC pipe. Bearing to Grand Teton $=275^{\circ}$. Shadow Mountain $7.5^{\prime}$ quad., $43^{0} 43^{\prime} 31^{\prime \prime} \mathrm{N}, 110^{\circ} 36^{\prime} 45^{\prime \prime} \mathrm{W}$.

GTR - Class B rod point, $1.5 \mathrm{~m}$ long, driven to refusal in, and nearly flush with the surface at the south end of a bedrock ridge. The bench mark is the apex of an equilateral triangle east of the East Side Road with power poles MM14/KA122 and KM115. Upper $1 / 2 \mathrm{~m}$ sheathed in $20 \mathrm{~cm}$-diam. PVC pipe. Bearing to Grand Teton $=277^{\circ}$. Shadow Mountain 7.5' quad., $43^{\circ} 43^{\prime} 12^{\prime \prime} \mathrm{N}, 110^{0} 36^{\prime} 53^{\prime \prime} \mathrm{W}$. 
Auxiliary Bench Marks

TPGT1 - Class B rod point, 1/2 m long, driven to refusal in, and nearly flush with the beach surface on the north shore of the Snake River, almost south of GTC. It is regarded as a temporary turning point to carry the leveling line across the Snake River. Moran 7.5' quad., 430 $45^{\prime} 37^{\prime} \mathrm{N}, 110^{0} 37^{\prime} 06^{\prime} \mathrm{W}$.

TPGT2 - $10 \mathrm{~cm}$-long, stainless steel rod with beveled top that projects $2 \mathrm{~cm}$ above the surface of a quartzite boulder, having a surface $0.5 \mathrm{~m} \mathrm{x} 0.5 \mathrm{~m}$ and projects $5 \mathrm{~cm}$ above the other boulders around. the boulder is located at water level on the south shore of the Snake River. It is regarded as a temporary turning point to carry the leveling line across the Snake River. Moran 7.5' quad., 434' $34^{\prime} \mathrm{N}, 110^{\circ} 37^{\prime} 07^{\prime} \mathrm{W}$.

TPGT3 - $10 \mathrm{~cm}$-long, stainless steel rod with beveled top that projects $2 \mathrm{~cm}$ above the surface of a red chert boulder, having a surface $0.5 \mathrm{~m} \times 0.5 \mathrm{~m}$ and projects $30 \mathrm{~cm}$ above the ground surface. The boulder is located on the north edge of the Deadman's Bar road, half way up the road from the top of the second main bench to the top of the third, about $5 \mathrm{~m}$ north of the road center line. It is regarded as a temporary turning point to carry the leveling line up the Deadman's Road between GTH and GTI. Elevation = 6720'a.s.1. Moran 7.5' quad., $43^{\circ} 45^{\prime} 28^{\prime}$ N, $110^{0} 37^{\prime} 00$ "W.

NPSRM - $10 \mathrm{~cm}$ bronze disk set in the top of a steel pipe that projects about $25 \mathrm{~cm}$ above the ground surface next to a 1/2 m-diameter, $30 \mathrm{~m}$-diameter, $30 \mathrm{~cm}$-high pile of rounded quartzite boulders at the south apex of the wye intersection between the Lost Creek and east Side roads, and $20 \mathrm{~m}$ south of a second identical reference mark. Disk is stamped U.S. Department of Interior Bureau of Land Management RM with a west-pointing arrow and reference distance of $28 \mathrm{ft}$. Bearing to Grand Teton $=260^{\circ}$ Shadow Mountain 7.5' quad., 43 $44^{\prime} 33^{\prime \prime} \mathrm{N}$, $110^{0} 36^{\prime} 00^{\prime \prime W}$.

6996 - $10 \mathrm{~cm}$ bronze disk set in the top of a steel pipe that projects about $25 \mathrm{~cm}$ above the ground surface next to a $1 \mathrm{~m}$-diameter, $30 \mathrm{~cm}$-high pile of rounded quartzite boulders $3 \mathrm{~m}$ northwest of fence corner and NPS property corner. Disk is stamped U.S. Department of Interior Bureau of Land Management T44NR115WCW1/16S36 1966. Bearing to Grand Teton $+271^{\circ}$. Elevation $=6996$ 'a.s.l. Shadow Mountain 7.5' quad., 43"44'07'N, $110^{0} 36$ '00"W. 